\title{
Entrepreneurial Path: Decoupling the complexity of entrepreneurial realisation
}

Dr. Kostas Galanakis, Nottingham Business School, Newton Building, 8th Floor

Burton Str, NG1 4BU, Nottingham, Email: kostas.galanakis@ntu.ac.uk

Dr. Paraskevi Giourka, Democritus University of Thrace, Unit of Innovation and

Entrepreneurship, Vas. Sofias 12, Building 3, Level 2 - Office 204, Engineering Campus of Xanthi, 67100 Email: pgiourka@gmail.com 


\title{
Entrepreneurial Path: Decoupling the complexity of entrepreneurial realisation
}

\begin{abstract}
Purpose (mandatory): The objective of this paper is to synthesise the socioeconomic context, personality, knowledge and social capital into a systemic framework, named the 'Entrepreneurial Path', that demonstrates the process of transforming initial entrepreneurial intentions to a growing venture. This systemic framework decouples the overall complexity of the entrepreneurial realisation to three main subsystems: entrepreneurial intentions and venture idea formation; barriers of transition from nascent to active entrepreneur; and, active and growing ventures.
\end{abstract}

Design/methodology/approach (mandatory): The paper employs a systemic thinking approach to decouple the complexity of the subject. Survey techniques and digital social network discussion forums were used for the collection of primary qualitative data from multiple stakeholders.

Findings (mandatory): The conceptual framework, named the Entrepreneurial Path, highlights the importance of different factors at each stage of the entrepreneurial realisation. Especially the importance of factors such as perceived desirability, feasibility, self-efficacy, network ties and social capital have been identified as central. Needs for managerial skills and resources for the new venture come to play only on the later stage. Each of those factors though, play a distinctive role in the different stages of the realisation and in dependence to the maturity of the entrepreneurial context.

Research limitations/implications (if applicable): Further research may examine whether these factors that have been identified by successful entrepreneurs and stakeholders are reflecting the experience for those who have not been successful in their effort to create their venture.

Practical implications (if applicable): The Entrepreneurial Path provides a supportive tool for: academics designing focused entrepreneurship education programmes and research; managers in intermediate structures to identify the specific needs of nascent and early stage entrepreneurs in comparison to the needs of entrepreneurs in the growth stage; and, for policy makers prioritising on supportive structures and institutions directing their actions to specific stages or barriers of the process or creating holistic and evolving structures based on the maturity of the entrepreneurial context.

Social implications (if applicable)

Originality/value (mandatory): The decoupling of the process of transforming initial entrepreneurial intentions to a growing venture demonstrates that different approaches are required in order to foster each one of the factors identified. Focusing on activities and resources on one stage at the time, or presenting parallel activities that reflect the different level of maturity of regions, institutions, individuals and societal perceptions may provide better service to nascent and active entrepreneurs, than considering treating entrepreneurial intentions as a unified process.

Keywords: 
Entrepreneurship; social capital; self-efficacy; network ties; entrepreneurial context; entrepreneurial intentions, systems thinking 


\section{INTRODUCTION}

Entrepreneurs are recognised as important players and indispensable capital in the world economy as they are one of the generators of employment and income (Etzkowitz, Webster, Gebhardt, \& Cantisano Terra, 2000). Start-ups, especially university spin-offs, are endogenous sources of innovation and growth, as they generate substantial spill over effect for their regional economy (Fretshner et al., 2013). Additionally, business survival rates and 'employability' chances have been shown to be higher in individuals with University entrepreneurship education than their non-academic colleagues (Kohn et al., 2010). In this context, policy makers and academics agree on the importance of designing policies and tools for encouraging and supporting entrepreneurship (Oosterbeek, Van Praag, \& Ijsselstein, 2010).

Many studies have examined the relationship between entrepreneurship education and entrepreneurial career choice with either trait approach or intention-based approaches (Fayolle et al., 2006; Matlay, 2008; Souitaris et al., 2007).

Entrepreneurship education is considered as one of the main tools for inspiring entrepreneurial spirit and equipping students with the entrepreneurial skills they need to create new ventures (European Commission, 2008; Kuratko, 2005). Educational institutions provide this necessary knowledge and capabilities (Rasmussen \& Sørheim, 2006). Although there are open questions whether education programmes do enough to transform intentions to actual entrepreneurial actions (Dewett and Gruys, 2007; Zampetakis, et al., 2011). Research has shown that intentions of students taking entrepreneurship courses seem to be increased at the end of the students' participation in entrepreneurship programs compared to the beginning (Souitaris et al. 2007). 
However, despite all the interest and recognition during the last few decades, research in the area of entrepreneurship tends to homogenise around the themes of strategy, performance, entrepreneurial attitude, and management. Areas such as personal capital (knowledge, social and professional networks), the entrepreneurial context and how these affect the entrepreneurial realisation at different levels is rather emerging themes that haven't yet been considered systematically (Prá Martens et al., 2016).

The objective of this paper is to synthesise the socioeconomic context, personality, knowledge and social capital into a systemic framework, named the 'Entrepreneurial Path', that demonstrates the process of transforming initial entrepreneurial intentions to a growing venture. This systemic framework decouples the overall complexity of the entrepreneurial realisation to three main subsystems: entrepreneurial intentions and venture idea formation; barriers of transition from nascent to active entrepreneur; and, active and growing ventures. The aim is to provide a guideline to tailor research, supportive policies and educational programmes that foster entrepreneurial intentions and activities for each of the different stage. One research question has been shaped to achieve the objective: How are the personal, socioeconomic and institutional contextual factors interrelate to shape the different stages of the entrepreneurial process?

We employed a mix of traditional and contemporary research techniques, exploring experiences and perceptions across Europe regarding the nature of skills and characteristics of entrepreneurs, and depicting factors fostering entrepreneurial activity and contributing to the success of an entrepreneurial venture. These empirical findings are synthesised with previous studies on a systemic framework, using a system thinking approach. Section two describes the methodology and practices used in this study. The following section builds the conceptual framework of the entrepreneurial path, step-by-step, based on previous research. 
Section four provide the analysis of the primary data based on the conceptual framework. The paper closes with the discussion of the research question and conclusions of this research that illustrate the complexity of the overall conceptual framework.

\section{THE ENTREPRENEURIAL PATH CONCEPT}

The phases of the entrepreneurial process and the importance of entrepreneurial attitudes and the characteristics of entrepreneurs are addressed by the Global Entrepreneurship Monitor (GEM) using a socioeconomic approach (Bosma, Wennekers, \& Amorós, 2012). Four distinctive phases are identified in this model: potential entrepreneurs shape their beliefs and develop their abilities with an intention to choose an entrepreneurial career path; early-stage entrepreneurial activity leads to nascent or actual new ventures; established business; and, if either the early stages or the established business fail, discontinuation. Traits closely related to entrepreneurial potential such as innovativeness, locus of control, risk taking propensity and tolerance for ambiguity, are related to the intentions of individuals to start a new venture (Gurel et al., 2010; Liñán and Chen, 2009; Segal et al., 2005). In addition, psychological and socio-cultural backgrounds of individuals such as cultural values, social exposure, entrepreneurial disposition, family tradition, education, as well as demographic factors have also been identified to have an effect on entrepreneurial intentions along with entrepreneurial self-efficacy (Gurel et al., 2010; Lans et al., 2010; Liñán and Chen, 2009; Pruett et al., 2009; Shinnar et al., 2012;) in contrast to entrepreneurial planning (Cox, 2014).

Expanding the GEM framework to include the personal traits that affect the decision and the progress of the entrepreneurial process and the social traits that present opportunities or threats on any economic activity create a new generic conceptual framework (Figure 1). This framework provides an overall view of the path and the possible influences in the entrepreneurial realisation. 


\section{[Insert Figure 1]}

Figure 1. The overall entrepreneurial realisation process

The next sections illustrates in more detail the factors and their interrelation that influence each stage: the initial entrepreneurial intentions and the generation of venture ideas; the transition barrier to an active entrepreneur; and, the creation and growth of a new ventures.

\section{FORMATION OF ENTREPRENEURIAL INTENTIONS AND VENTURE IDEAS}

It can be argued that the social and cultural environment may have an effect on intentions that result to the choice of an entrepreneurial career (Shaphero, 1982). Factors like family, peer groups, ethnic group, educational and professional context seem to influence someone's decision on creating a new venture. More recent, Klyver et al. (2012) showed that, often, the most important force toward an entrepreneurial career is the personal ties to an entrepreneurial network through their family, social or professional connections. These networks play a multifaceted role, in the realization of entrepreneurship and the entrepreneurial process itself, relating for example, ideas with market needs (Klyver et al., 2012) or the success of the venture (Hoang and Antonic, 2003; Jack, 2010; Pellinen, 2014). In addition, Scholin et al (2016) posit that desire and ability for entrepreneurial career intentions accumulate gradually within an individual at a family context while they are triggered by external events or personal reveleation (Scholin et al., 2016).

Other studies show that gender difference in the attitude towards engaging to entrepreneurial activity can be linked to environment conditions and practices of entrepreneurial education (Verheul, Thurik, Grilo, \& van der Zwan, 2011). Preference for self-employment is an important factor and relevant research has shown that men have a higher preference for self- 
employment than women (Blanchflower, Oswald, \& Stutzer, 2001; Grilo \& Irigoyen, 2006). Furthermore, male entrepreneurs benefit from a more diverse network ties although women have a significant more positive attitude towards networking, especially once the venture has been created (Dawson, et al., 2011). Research suggests that women seem to attach a high value to the institutional supportive framework and to the specific, socio-economic context, considering it as a major factor of uncertainty more often than an environment for opportunities, when deciding whether or not to run a business. Although they show a similar lever of belief on being capable of taking control of their own lives (Verheul, Thurik, Grilo and van der Zwan, 2011).

[Insert Figure 2]

Figure 2. Formation of Entrepreneurial Intentions and Venture Ideas

\section{TRANSITION BARRIER FROM NASCENT TO ACTIVE ENTREPRENEUR}

Perceptions and attitudes are often crucial factors that allows an individual to overcome the barrier of transition from nascent to active entrepreneurship. Shapero (1982), in his research, states that the intent to start a business derives from perceptions of both, desirability and feasibility, which are partly formed by the person's knowledge and understanding and partly by the institutional environment. The Theory of Planed Behaviour (TPB) and the Intentionbased models (Ajzen, 1991) have been frequently used to explain the mental process leading up to founding a business. TPB presents three motivational factors, or antecedents influencing entrepreneurial behaviour (Ajzen, 1991): Attitude towards start-up (Personal 
Attitude) refers to the extent to which the individual holds a positive or negative personal valuation about becoming an entrepreneur (Autio et al., 2001). Subjective Norms measures the perceived social pressure to carry out - or not entrepreneurial behaviours. These norms refer to the perception that reference people for example, family, friends, and role models would approve of the decision to become an entrepreneur, or not. This is supported by the work of Dunn and Holtz-Eakin (2000) that identify parents' own entrepreneurial success to have an impact on the transition of an individual into self-employment. Perceived Behavioural Control (PBC) refers to the perception of the ease or difficulty of becoming an entrepreneur. This perceived feasibility is also linked to availability of financial capital that is shown to have a large influence on the transition phase (Dunn and Holtz-Eakin, 2000).

In addition, trust in entrepreneurial activities is another element that may facilitate or hinder the transition. Trust refers not only to personal relations but is also linked to institutional trust. Institutional trust refers to the basic level of reliability of exchanges and also to the enforcement of laws and regulations when required (Welter \& Smallbone, 2006). This provides a transparent environment for enterprises to operate and grow without extra barriers. A transparent institutional framework supports the notion of feasibility as it reduces potential barriers. This however, requires a level of institutional maturity that comes in the long-term as a consequence of the economic growth. Propensity to act (Segal et al., 2005) - which refers to the personal disposition to act on one's decision, echoing the will of a person to act ("I will do it") - reflects the concept of self-efficacy. 'Highest self-efficacy', or the so called 'soft skills', often considered in a much higher importance than the knowledge or practical business skills in order to engage in a new venture. For example: 'ability to spot and recognise opportunities'; 'high personal perseverance'; 'high human and social capital' and superior 'social skills'. These skills affect the extent to which an individual believes that can organise prioritise and effectively execute actions to accomplish her/his ideas (Bridge, 2009; 
Jung, 2001, Lamine et al., 2014), to withstand and quickly overcome adversity (Markman \& Baron, 2003), or the ability to distinguish between high potential and low potential opportunities, obstacles and risks before they become obsolete or unbearable (De Clerq, 2006).

\section{[Insert Figure 3]}

Figure 3. The transition barrier from nascent to active entrepreneur

\section{ACTIVE AND GROWING VENTURES}

Ulhøi (2005) posits that economic activity is embedded in social relations and such relations influence the creation of new ventures and the 'art of running a business'. This position is further supported by Gnyawali and Madhavan (2001) who argue that network relations may increase the likelihood of competitive advantage mainly because of increased access to resources and information. Especially in small communities, social skills which is defined as 'an individual's ability to effectively develop, maintain, and utilize social capital can provide access to information and finance (Bauernschuster, et al., 2010, Jonsson, 2014, Lamine et al., 2014). Welter and Smallbone (2006) support the idea that the potential to use networks and social relations in building a new venture is based on the principle of trust. Research in the field has shown that building heterogeneous networks increases the likelihood of creating a venture (Renzulli, et al., 2000) and assists in creating legitimacy within the market (Aldrich, 2000). Legitimacy, especially for a new venture and particularly for innovative entrepreneurs is linked with being trusted by suppliers, customers and creditors.

\section{[Insert Figure 4]}

Figure 4. The active and growing venture 
This paper builds on previous research described above regarding the linkage of different factors to the different stages of realising a new venture. The conceptual framework developed emphasizes on decoupling the complexity of entrepreneurial intentions becoming entrepreneurial realisation. By examining how these factors help or hinder the realisation of a new venture we can analyze their impact on individuals and thus inform policies and educational programs.

\section{METHOD AND RESEARCH STRATEGY}

The focus of systems thinking is on helping to improve decision making by analysing the processes through which decisions emerge and by improving how the system works. Systems thinking perceive a problem as a set of circumstances with extreme ambiguity and sometimes disagreement about its definition between the people or organisations that are involved and who do not always operate in a predictable manner. The framework is constructed step by step and aims, through the insights from the debates that take place between theory, empirical observations and interconnections of different aspects, to make explicit the aspects of reality and understand why reality reacts in such a way (Checkland, 1993; Pidd, 1996). In this case to understand what shapes and influences entrepreneurial intentions and actions at the different stages of the entrepreneurial realisation

The empirical part of the study adopted an explanatory method, using qualitative data. The qualitative data were collected in two stages: a) open-ended questions and semi-structured interviews (Bryman, et al., 2008); . b) virtual discussion forums, using digital social networks for depicting perceptions and create debates between different stakeholders. This combination of approaches reinforce the systems thinking modelling process, which is based on the dialog between different stakeholders and by providing current empirical evidences to 
observations that derive from previous research and debating factors that may lead to conflicting directions (Pidd, 1996).

\section{(a) THE CHARACTERISTICS OF THE FIRST STAGE}

A questionnaire survey, including open questions, was designed to depict the experiences and perceptions, regarding factors that may lead to become and succeed as an entrepreneur. The questionnaire included the following categories of questions:

(a) the profile of the young entrepreneurs (Appendices A.1,A.2);

(b) their experiences and their perceptions regarding the nature of entrepreneurial activity;

(c) the personality characteristics required to undertake entrepreneurial activity; and,

(d) the skills required by entrepreneurs to succeed.

An invitation was sent to 100 young entrepreneurs who have started entrepreneurial activity in the last five years ${ }^{1}$. Fifty three questionnaires were completed and were codified based on content analysis (Bryman, 2012). The codification during the analysis resulted in two categories: C1 Operational type of factors, and C2: Personality type of factors.

In order to complement the findings and ensure that the data provide a better understanding of the survey results, the researchers conducted interviews based on the initial data codification. These interviews created a 'trail-story' for each participant ${ }^{2}$.

\section{(b) CHARACTERISTICS OF THE VIRTUAL FORUMS}

\footnotetext{
1 These actions have been implemented through the project "STARTENT: Fostering Business-University Partnerships for Entrepreneurship Education in Europe", co-funded by the European Commission, DG Enterprise and Industry under the call "Entrepreneurial culture of young people and entrepreneurship education". The overall objective of the project was to contribute to developing the entrepreneurial culture of young people, and to improve entrepreneurship education in Europe. www.startent.eu ${ }^{2}$ Complete texts of the replies in the form of "success stories" are published at http://www.startent.eu/publications
} 
In parallel the researchers developed a set of digital discussion forums. These created virtual social interaction with peers, with the use of digital social networks as a means of the recent experienced social reality (Denzin \& Lincoln, 2005). The discussion forums were activated on LinkedIn for a period of three months and managed by the researchers. The participants were invited by the researchers through an original network of contacts across Europe. Further participants were invited by the original participants ensuring their genuine identity to the organisers of the forums. The discussion forums initial questions ${ }^{3}$ were:

- Entrepreneurs: Are they born or made?

- Is Entrepreneurship a team or an individual sport?

- Does university foster entrepreneurship?

- Male vs. Female Entrepreneur: Who does it better? Are they working under the same conditions?

Twenty-five persons participated in the discussion forums with a total of more than 80 input posts. The participants were a mix of academics, students, young entrepreneurs, professionals, business people and professionals in intermediary organisations. The discussions focused mainly on the factors influencing entrepreneurial intentions and the transition toward active entrepreneur from the personality perspective and the socioeconomic perspective.

Capturing the perception of informants through virtual forums have advantages but also limitations. Advantages of asynchronous communication of time and place can be the extended access to participants, compared to face to face interviews as there is no need to identify a convenient time and place for capturing the information (Coomber, 1997) while ensuring a degree of anonymity (Bampton and Cowton, 2002). Another advantage is that it reduces the cost of travel and provides the possibility to interview in a foreign language using translation tools. Limitations can be that the chance of a spontaneous answer to a question is smaller as the informant has more time to reflect to a question. It depends of course to the nature of the question if this spontaneity is an advantage or a disadvantage. Another

\footnotetext{
${ }^{3}$ The complete discussions can be followed at www.startent.eu LinkedIn discussions.
} 
limitation is the reduction of social cues as the body language cannot be used as a source of extra information. In order to reduce the effect of these disadvantages the researchers monitored the activity in the groups and often used humorous and informal language to create a relaxed environment among the participants, triggering replies from other participants and often used emoticons to express feelings and social cues. Finally, disadvantage of asynchronous communication of place is that the interviewer has no view on the situation in which the interviewee is situated (Opdenakker, 2006). This last disadvantage has little effect in our study as the participants were invited by a network of contacts across Europe.

\section{ANALYSIS OF RESULTS}

The conceptual framework that has been formed at the theoretical part of the paper (Figure 2, $3 \& 4)$ is compared with the findings from the primary research. Participant in the discussion forum 'The Entrepreneurs: Are they born or made?' quoted an interview with Herb Kelleher, chairman and CEO of Southwest Airlines, (Babson Insight Staff, 2003), concluding that there is no specific list of personal features which lead to entrepreneurial activity. The answer lies in the right mix of personal attributes, which form an engaging and proactive work ethos, and the encouragement and enrichment of this ethos with skills that are developed both by the environment and the broader education that a person may receive.

\section{FINDINGS IN RELATION TO FORMATION OF INTENTIONS AND IDEAS STAGES}

Participants in 'The Entrepreneurs: Are they born or made?' discussion forum agreed with Autio et al (2013) that the socio-economic context affects significantly the entrepreneurial intentions. The socio-economic environment provides triggers that we tend to treat as opportunities or necessities and that entrepreneurship is one of the approaches to transform them into valuable activities. If the entrepreneurial approach has been cultivated over time and considered as central under the subjective norms, then it is more likely for a young 
person to consider such a career, especially when they have personal or family ties with others that are considered as successful (role models).

The nascent entrepreneurs then employee their knowledge and skills that earned from their broader education to direct the core of their activity. The triple role of universities to transfer and generate knowledge, form personalities and lead society's perceptions and actively influence policy making and regulation forming, was raised by several members of the 'Does University foster entrepreneurship?' forum. In parallel they mentioned the role of educational systems in supporting and boosting soft skills, such as creativity and adaptability, and interdisciplinary collaboration. Participants highlighted that universities need to encourage a holistic educational offering integrating science/technology knowledge, managerial/business skills and soft skills development in order for their students to be able to invest in their creativity or be adaptable to new skill requirements. Participants commented that the best ideas come when people from different disciplines (engineering, science, arts and management) come together 'shoulder to shoulder' and successfully interchange ideas. The group effect nurtures creativity and may be demonstrated in many fields, such as the case of the 'Residencia de Estudiantes ${ }^{4}$, established as early as 1910, with many famous artists and scientists as residents. Indicatively, a speech from Sir Ken Robinson was quoted ${ }^{5}$ in the forums, who has been an internationally recognised leader in the development of education on creativity and innovation (Robinson, 2001, 2009). He encourages policy makers and educators to rethink their role and build the right collaborative structures to sustain and enrich the natural creative spirits of every young person.

\section{[Insert Table 1]}

Table 1. Discussion forums main observations

\footnotetext{
${ }^{4}$ http://www.residencia.csic.es/en/info/history.htm

5 http://www.ted.com/talks/ken_robinson_says_schools_kill_creativity.html
} 


\section{FINDINGS IN RELATION TO THE TRANSITION BARRIERS}

Institutions and regulations in combination with barriers raised by bureaucratic systems, and lack of a formal welfare system - as mentioned in the 'Male vs Female entrepreneurs forum discourages young people from engaging in entrepreneurial activities. Furthermore, participants agreed that the education system should lead the effort to correct the misconception that entrepreneurship is a male only game. In the 'Male vs. Female entrepreneur' forum participants agreed that the reason that new ventures are created predominantly by men is not because they are better entrepreneurs but rather due to the different roles that society expects men and women to play and the nature and availability of the supporting structures. The anticipation of their roles make it easier for men to engage in entrepreneurial activities. In the 'Does University foster entrepreneurship?' and the 'Male vs. Female entrepreneurs' forums the participants argued that a supportive entrepreneurial and institutional context is a prerequisite for both male and female entrepreneurship presence. Often though this context favours men. To expand female participation in entrepreneurship, it is a matter of building the right structures and directing the initiatives strategically for both genders. Furthermore, participants in the forums mention that in societies, which have replaced their welfare systems with family networks, such as in southern Europe, universities could lead on the design and development of a sustainable welfare system that will eventually benefit both the economy and society at large - a welfare system that will offer relief and security in case of failure (e.g. re-training and micro-financing), or support of family needs (e.g. provision of child-care services).

The issue of supportive structures (discussed in the 'Does University foster entrepreneurship?' and cross-disciplinary competence (raised in the forum, 'Is 
entrepreneurship a team sport or an individual sport'?) raised in the discussion forums. Practices employed by leading universities include 'idea labs', enterprise support centres, incubators, networking events, idea/business competitions and a number of undergraduate and postgraduate level courses related to entrepreneurship with the active involvement of entrepreneurs and business people were identified as best practices across Europe. The participants in this discussion broadly agreed that entrepreneurial activity benefits from the safe environment that academic institutions present. These structures in addition engage individuals to group activities and ideas are exchanged easier. The group effect, agreed in the discussion, raises the perceived desirability and feasibility. This is especially true in the transition stage of transforming an original business idea into a new venture.

However, some participants observed that although groups are ideal for creativity and idea generation, it is always necessary to have one 'leader' or 'champion' who will push things forward and take the risk of implementation. It was also discussed in the forum that entrepreneurial firms that started from a group of people often fail unless one person in the group takes on the role of leader and either continues alone or successfully remodels the organisational structure towards a management team, providing clear vision and ambition. As the young entrepreneurs described the best characteristics of entrepreneurs (Table 3) are persistent (Adomako et al., 2016) and willing to take the risk when other do not.

\section{FINDINGS IN RELATION TO THE ACTIVE AND GROWING VENTURES STAGES}

Kauffman Foundation demonstrated that more than $95 \%$ of entrepreneurs have a university degree, with $47 \%$ at postgraduate or doctorate level, a much higher proportion than in the general population (Wadhwa, Raj, Krisztina, \& Alex, 2009). Our survey shows that $68 \%$ of the participants held a university degree - six held a $\mathrm{PhD}$ (Appendix A). Furthermore two third of the participants in our survey founded their new ventures around their area of studies, 
applying their knowledge and skills as they identified a new opportunity emerging from advances in their scientific or technological field. However, one third considered entrepreneurial activity as a need for alternative employment. This results although they indicate that the majority of entrepreneurs have a high qualification level, defer from the Kauffman Foundation ones. This reflects that in Europe often entrepreneurial activity, especially in South Europe, comes as a result of necessity rather than choice.

In the survey, "entrepreneurial success" is explored from the perspective of the successful entrepreneur. Two categories of factors were identified, referring to operational capabilities (or dynamic capabilities as Teece and Pisano (2007) labels them) and personal attributes (Markman \& Baron, 2003; Stoltz, 2000, Fisher, 2014), shaping the 'art of running a business'. The capabilities that were mentioned more often by the young entrepreneurs were codified under the labels: 'address a need/opportunity/good product/differentiation'; 'continuous research and innovation'; 'team and teamwork'; 'persistence in achieving quality and continuous improvement; and, 'being reliable and trustworthy'. Regarding the personal attributes the participants mentioned that the key to success lies with the personal working ethos of the entrepreneur such as: 'professionalism and hard work'; being 'persistent and passionate'; 'open mindedness and adaptability'; 'Brave/Decisive/Confident'; 'Ambition/Vision' (Table 2). The need for 'financial resources' and a 'good plan' were mentioned in much lower frequency. These factors came in relation to the ability of an entrepreneur to attract investment and inspire trust. These together with the ability of an entrepreneur to create and maintain networks form the concept of entrepreneurial social capital. Finally the ability and maturity of the financial system to support with different ways a new venture to escape the 'death valley' (e.g. venture accelerators, business angels, enterprise support centers) and accelerate its growth (e.g. high risk funds) becomes apparent in this stage of the entrepreneurial realisation as commented by the young entrepreneurs. 
Table 2. Perception of the key factors to be successful as an entrepreneur

Table 3. Perception of best characteristics of an entrepreneur

\section{DISCUSSION OF THE ENTREPRENIURIAL PATH CONCEPT}

Each region or individual has a different level of understanding and capacity to explore entrepreneurship. From the point of view of education and supportive structures, the progressiveness of the framework demonstrates a significant implication for presenting parallel activities, which are tailored to the different stage that their socioeconomic and entrepreneurial environment is. For example investing on breeding perceived desirability and feasibility to nascent entrepreneurs and to cultivate the work ethos, social capital and soft skills of students, when the environment is not mature enough.

The construction of the Entrepreneurial Path concept demonstrated that the early stages of career intentions, in the entrepreneurial realisation, are affected mainly from personal and societal factors (Figure 2). The individual interrelates knowledge, skills and experiences (e.g. role models) to direct career intentions towards an entrepreneurial direction. Societal norms and perceptions may encourage or discourage such activities and often redirect these intentions to career paths that are considered by society as most rewarding. Individuals that pursue an entrepreneurial career against the societal norms often are considered by their contemporaries as rebellions and most passionate, whom the society, paradoxically, may celebrates later as paradigms of success.

The individuals that follow an entrepreneurial career need to transform intentions to concrete ideas and anticipate such path as the most desirable and feasible option (Figure 3). Their ethos, the fusion with others and their knowledge on the area of their venture may increase 
the desirability and feasibility perceptions. Till this stage the need for resources or difficulties in relation to the management of the business have not raised yet, or overlooked by the desire for action. On the other hand, the socioeconomic and institutional context might be bypassed by personal qualities, however, this might be the exception rather than the norm, highlighting the need for a supportive context. In some cases institutions may be unprepared to overcome stereotypes and reduce barriers (e.g. bureaucracy, or gender stereotypes). In other cases entrepreneurship may be associated with corruption or the legal and regulatory system might be considered unstable, slow or favourites specific interests. In such cases the role of the personal leadership is the crucial factor that amplifies the entrepreneurs' actions escaping contextual barriers. On the other hand socioeconomic and institutional context may become a framework that provides support and boost personal efforts. For example, it may provide a safe space and regulation to try and fail if necessary, or networks to encourage 'group effect'.

Having established a new venture and aiming to growing it, entrepreneurs employee a different set of qualities. At this stage the personal attributes represent a flexible and adaptive professional who is able to initiate and maintain networks, inspire trust and attract financial and other resources. Furthermore, the social capital of the entrepreneur in combination to the social capital and capabilities of the whole venture (e.g. partners, employees, intellectual property) take the front stage of importance. The ability of the entrepreneur to manage these resources under a specific institutional context and adapt them tirelessly highlights the ability of the new venture to survive the first few years and grow over time. (Figure 4). The institutional framework though has a responsibility to present a mature and complete set of structures available to any entrepreneur that may require them.

\section{CONCLUSIONS}


We conducted this research employing survey techniques in combination to innovative tools that contemporary technologies, such as the digital social networks, provide us. Often entrepreneurship is considered as one homogeneous activity that transits from interest and opportunity recognition (nascent entrepreneur) to exploitation through a new venture creation (active entrepreneur). However the overall entrepreneurial path (Figure 5) illustrates a rather complex network of personal and contextual factors that are deployed progressively into the entrepreneurial realisation. The decoupling of the stages demonstrate that different approaches are required in order to foster each one of those factors. Focusing activities and resources on one stage at the time, or presenting parallel activities that reflect the different level of maturity of regions, institutions, individuals and societal perceptions may provide better service to nascent and active entrepreneurs, than considering entrepreneurship as a unified process. The responses in this research demonstrate a rich activity of supportive actions across Europe, however these are referred as best practices and not as the norm. Becoming the norm, and be designed to reflect the contextual framework, these structures and educational programmes, have the potential to cover the needs of nascent entrepreneurs exploring their ideas and overcoming the transition barriers.

Thus, a reshaping on the design of supportive structures (e.g. training programmes, incubators, co-working spaces, accelerators), is suggested by the framework in order to capture that level of maturity.

I Hence, this analytical framework may serve as a supportive tool for academics designing focused entrepreneurship education programmes or research, managers in intermediate structures to identify the specific needs of nascent and early stage entrepreneurs and for policy makers prioritising on supportive structures, institutions and regulations. 
Further research may examine whether the factors that have been identified by participants to play a key role in the different stages of the entrepreneurial realisation are also applicable for those who have not been successful in their effort to create or grow their venture. This further analysis may provide information on the, factors that encourage entrepreneurs who disengage at one of the stages or failed in their original venture to reengage with the process. Such factors may be related for example, with personal optimism, or the legal framework.

\section{REFERENCES}

Adomako, S., Danso, A., Uddin, M., Ofori-Damoah, J. , (2016),"Entrepreneurs', cognitive style and persistence", International Journal of Entrepreneurial Behavior \& Research, Vol. 22 Iss 1 pp. -.

Ajzen, I. (1991), "The theory of planned behavior", Organizational behavior and human decision processes, Vol 50, No 2, pp. 179-211.

Aldrich, H. (2000). Entrepreneurial strategies in new organizational populations in R. Swedberg (Ed.), Entrepreneurship: The social science view. University Press, Oxford, pp. 211-228.

Babson Insight Staff. (2003), "Entrepreneurs: Born or made? A conversation with Herb Kelleher of Southwest Airlines", available at http://searchcio.techtarget.com/news/924412/Entrepreneurs-Born-or-made-Aconversation-with-Herb-Kelleher-of-Southwest-Airlines (accessed 06/02/2012). 
Bauernschuster, S., Falck, O., and Heblich, S. (2010), "Social capital access and entrepreneurship", Journal of Economic Behavior \& Organization, Vol 76, No 3, pp. 821-833.

Blanchflower, D. G., Oswald, A., and Stutzer, A. (2001), "Latent entrepreneurship across nations" European Economic Review, Vol 45 No 4-6, pp. 680-691.

Bosma, N., Wennekers, S., and Amorós, J. E. (2012), "Entrepreneurs and Entrepreneurial Employees Across the Globe", 2011 Extended Report Global Entrepreneurship Monitor available at http://www.babson.edu/Academics/centers/blank-center/globalresearch/gem/Documents/GEM\%202011\%20Extended\%20Report\%20VF\%20rev.pdf (accessed 28/02/2016).

Bridge, S., O’Neill, K. and Martin, F. (2009), Understanding Enterprise: Entrepreneurship and Small Business (3rd ed.), Palgrave Macmillan, Basingstoke.

Bryman, A. (2012), Social research methods (4th ed.). Oxford University Press, Oxford.

Bryman, A. Becker, S., and Sempik, J., (2008), "Quality criteria for quantitative, qualitative and mixed methods research: A view from social policy", Social Research Methodology, Vol 11, No 4, pp. 261.

Checkland, P. (1993), Systems Thinking, Systems Practice, John Wiley \& Sons, Chichester, New York, Brisbane, Toronto.

Coomber, Ross (1997). Using the Internet for survey research. Sociological Research Online, 2(2). Available at:http://www.socresonline.org.uk/socresonline/2/2/2.html [Access: September 07, 2016].

Cox, K., (2014), "Fundamental entrepreneurial planning processes: resource assessment and opportunity evaluation", The International Journal of Entrepreneurship and Innovation, Vol 15, No 2, pp. 79-88. 
Dawson, C. Fuller-Love, N., Sinnott, E. and O’Gorman, B., (2011), "Entrepreneurs' perceptions of business networks: does gender matter?", The International Journal of Entrepreneurship and Innovation, Vol 12, No 4, pp. 271-281.

De Clerq, D. and. Arenius, P. (2006), "The Role of Knowledge in Business Start-up Activity", International Small Business Journal, Vol 24, No 4, pp. 339-358.

Denzin, K. N., \& Lincoln, S. Y. (2005). The Sage handbook of qualitative research (5th ed.). California: Sage Publications.

Dewett, T., and Gruys, M. (2007), "Advancing the case for creativity through graduate business education", Thinking Skills and Creativity, Vol 2, pp. 85-95.

Druihe, C. and Garnsey, E., (2002), "Tracking the Emergence and Progress of University Spinout Cases", in IEEE International Engineering Management Conference, Cambridge.

Dunn, T. and Holtz-Eakin, D. (2000), "Financial capital, human capital, and the transition to self-employment: evidence from intergenerational links", Journal of Labor Economics, Vol. 18 No. 2, pp. 285-305

Etzkowitz, H., Webster, A., Gebhardt, C., and Cantisano Terra, B. R. (2000), "The future of the university and the university of the future: evolution of ivory tower to entrepreneurial paradigm", Research Policy, Vol 29, pp. 313-330.

European Commission, (2008), Entrepreneurship in higher education, especially in non business studies, Final Report. Enterprise and Industry Directorate - General.

Fayolle, A., Gailly, B., and Lassas-Clerc, N. (2006), "Assessing the impact of entrepreneurship education programmes: a new methodology", Journal of European industrial training, Vol 30, No 9, pp. 701-720.

Grilo, I., and Irigoyen, J. M., (2006), "Entrepreneurship in the EU: To wish and not to be", Small Business Economics, Vol 24, No 4, pp. 305-318. 
Gurel, E., Altinay, L., and Daniele, R. (2010), "Tourism students' entrepreneurial intentions", Annals of Tourism Research, Vol 37, No 3, pp. 646-669.

Hajizadeh, A., Zali, R.Z., , (2016),"Prior knowledge, cognitive characteristics and opportunity recognition", International Journal of Entrepreneurial Behavior \& Research, Vol. 22 Iss 1 pp. -

Hoang, H., and Antoncic, B. (2003), "Network-based research in entrepreneurship: a critical review", Journal of Business Venturing, Vol 18, No 2, pp. 165-187.

Honig, B. (2004), "Entrepreneurship Education: Toward a Model of Contingency-Based Business Planning", Academy of Management Learning and Education, Vol 3, No 3, pp. 258-273.

Jonsson, S. (2014), "Entrepreneurs' network evolution - the relevance of cognitive social capital", International Journal of Entrepreneurial Behaviour and Research, Vol. 21, No 2, pp.197-223.

Jung, D. I., Ehrlich, S.B., De Noble, A.E. \& Bok Baik, K., (2001), "Entrepreneurial SelfEfficacy and its Relationship to Entrepreneurial action: A Comparative study between the US and Korea", Management International, Vol 6, No 1, pp. 41-53.

Klyver, K., Hunter, E. and Watne, T., (2012), "Entrepreneurial ties and innovativeness in the start-up decision", The International Journal of Entrepreneurship and Innovation, Vol 13, No 3, pp. 153-163.

Kohn, K., Ulrich, K. and Spengler, H., (2010), "Annual Analysis of Structure and Dynamic of Entrepreneurship in Germany", Frankfurt Main Entrepreneurship Education, Vol 1 No 1, pp. 65-86.

Kuratko, D.F., (2005), "The Emergence of Entrepreneurship Education: Development, Trends, and Challenges", Entrepreneurship: Theory \& Practice, Vol 29, No 5, pp. $577-597$. 
Lamine, W., Mian, S., and Fayolle, A. (2014), "How do social skills enable nascent entrepreneurs to enact perseverance strategies in the face of challenges? A comparative case study of success and failure", International Journal of Entrepreneurial behaviour and Research, Vol 20, No 6, pp. 517-541.

Lans, T., Gulikers, J., and Batterink, M. (2010), "Moving beyond traditional measures of entrepreneurial intentions in a study among life - sciences students in the Netherlands", Research in Post - Compulsory Education, Vol 15, No 3, pp. 259-274.

Liñán, F. (2004), "Intention-based models of entrepreneurship education", Piccolla Impresa/Small Business, Vol 3, No1, pp. 11-35.

Liñán, F., \& Chen, Y. W. (2009), "Development and Cross - Cultural application of a specific instrument to measure entrepreneurial intentions", Entrepreneurship Theory and Practice, Vol 3, No 3, pp. 593-617.

Maman, D. (2000), "Who accumulates directorships of big business firms in Israel?: Organizational structure, social capital and human capital", Human Relations, Vol 53, No 5, pp. 603-630.

Markman, G. D., and Baron, R. A. (2003), "Person-entrepreneurship fit: why some people are more successful as entrepreneurs than others", Human Resource Management Review, Vol 13, No 2, p. 281.

OECD, (2009), The impact of the global crisis on SMEs and Entrepreneurship financing and policy responses, in C. f. e. OECD, SMEs and Local Development (Ed.). Paris.

Oosterbeek, H., Van Praag, M., and Ijsselstein, A., (2010), "The impact of entrepreneurship education on entrepreneurship skills and motivation", European Economic Review, Vol 54, pp. 442-454.

Opdenakker, Raymond (2006). Advantages and Disadvantages of Four Interview Techniques in Qualitative Research [44 paragraphs]. Forum Qualitative Sozialforschung / Forum: Qualitative Social Research, 7(4), Art. 11, http://nbn-resolving.de/urn:nbn:de:0114-fas0604118. 
Pellinen, K., (2014), "The interplay of entrepreneurial and network activities in the entrepreneurial process: a relational analysis", The International Journal of Entrepreneurship and Innovation, Vol 15, No 1, pp. 17-28.

Pidd, M., (1996), Tools for Thinking. Modeling in Management Science, John Wiley \& Sons, Chichester, New York, Brisbane, Toronto, Singapore.

Pruett, M., Shinnar, R., Toney, B., Llopis, F., and Fox, J. (2009), "Explaining entrepreneurial intentions of university students: a cross-cultural study", International Journal of Entrepreneurial Behaviour \& Research, Vol 15, No 6, pp. 571-594.

Rasmussen, E. A., and Sørheim, R. (2006), "Action-based entrepreneurship education", Technovation, Vol 26, No 2, pp. 185-194.

Robinson, K. (2001), Out of Our Minds: Learning to be Creative. Wiley, Capstone.

Robinson, K. (2009), The Element: How Finding Your Passion Changes Everything. Penguin.

Segal, G., Borgia, D., and Schoenfeld, J., (2005), "The motivation to become an entrepreneur", International Journal of Entrepreneurial Behaviour and Research, Vol 11, No 1, pp. 42-57.

Shapero, A. (1982), Social dimensions of entrepreneurship, In C. Kent et al. (Eds.), The encyclopedia of entrepreneurship: pp. 72-90, Prentice Hall, Englewood Cliffs.

Shinnar, R. S., Giacomin, O., and Janssen, F., (2012), "Entrepreneurial perceptions and intentions: the role of gender and culture", Entrepreneurship Theory and Practice, Vol 36, No 3, pp. 465-493.

Scholin, T., Broome, P., Ohlsson, H. (2016), "Self-Employment: The significance of families for professional intentions and choice of company type", International Journal of Entrepreneurial Behaviour and Research, Vol. 22, Iss: 3, pp. 329-345. 
Souitaris, V., Zerbinati, S. and Al-Laham, A., (2007), "Do entrepreneurship programmes raise entrepreneurial intention of science and engineering students? The effect of learning, inspiration and resources", Journal of Business Venturing, Vol 22, pp. 566591.

Ulhøi, J. P. (2005), "The social dimensions of entrepreneurship", Technovation, Vol 25, No 8, pp. 939-946.

Verheul, I., Thurik, R., Grilo, I., and van der Zwan, P., (2011), "Explaining preferences and actual involvement in self-employment: Gender and the entrepreneurial personality", Journal of Economic Psychology, (article in press).

Wadhwa, V., Raj, A., Krisztina, H., and Alex, S. (2009), "The Anatomy of an Entrepreneur: Family, Background and Motivation", available at http://papers.ssrn.com/sol3/papers.cfm?abstract_id=1431263, (accessed 28/02/2016).

Weitzel, U., Urbig, D., Desai, S., Sanders, M., and Acs, Z. (2010), "The good, the bad, and the talented: Entrepreneurialtalent and selfish behavior", Journal of Economic Behavior \& Organization, Vol 76, pp. 64-81.

Welter, F., \& Smallbone, D. (2006), "Exploring the Role of Trust in Entrepreneurial Activity", Entrepreneurship: Theory \& Practice, Vol 30, No 4, pp. 465-475.

Zampetakis, L., Gotsi, M., Andriopoulos, C. and Moustakis, V., (2011), “Creativity and entrepreneurial intention in young people", The International Journal of Entrepreneurship and Innovation, Vol 12, No 3, pp. 189-199.

Cristina Dai Prá Martens, Fabrício Martins Lacerda, Ana Claudia Belfort and Henrique Mello Rodrigues de Freitas , (2016),"Research on entrepreneurial orientation: current status and future agenda", International Journal of Entrepreneurial Behavior \& Research, Vol. 22 Iss 4 pp. 556 - 583 
Appendix A 